\section{Quinquefoliate Strawberry}

IT may interest botanical readers to know that we have here a variety of strawberry many petioles of which bear five leaflets. This kind of leaf is aiso transmitted to its offspring when propagated by runners, and I think it may be possible to raise from seed progeny the whole of whose petioles will bear five leaflets. It is an excellent variety in every respect; the fruit is symmetrical, and of rich flavour. When we consider that Duchesne's strawberry, Fragaria monophylla (described by Mr. Dyer in NATURE, vol. xxix. p. 215), was unifoliate, and that ordinary strawberries are trifoliate, this variety certainly is unique, and suggests still further possibilities of development in the genus Fragaria.

Driffield, April 16

SOME OF THE METEOROLOGICAL RESULTS OF THE TOTAL SOLAR ECLIPSE OF MAY 6, I $883^{1}$

$\mathrm{T}$ the expedition sent by the United States Govern1 ment to Caroline Island $\left(9^{\circ} 59^{\prime} 45^{\prime \prime} \mathrm{S}\right.$. lat. and $150^{\circ} 14^{\prime} 24^{\prime \prime} \mathrm{W}$. long.) to observe the total eclipse of May 6,1883 , provision was made for taking a series of meteorological observations on the occasion. The observations, which were of an elaborate description, are fully detailed and summarised by $\mathrm{Mr}$. Upton in the Report, and they present results of exceptional interest.

During the eclipse the velocity of the wind remained practically constant, and, so far as the readings of the radiation thermometers showed, the heat received by the earth was almost nil. The temperature of the air, which, previous to the eclipse, had been $84^{\circ} 5$, fell to $81^{\circ} 4$, or $0^{\circ} .1$ lower than it had been at 7 a.m., and $0^{\circ} .6$ lower than it was at 9 p.m. The amount of the temperature depression due to the withdrawal of the sun's heat was $3^{\circ} \cdot 9$; and, corresponding with this lowering of the temperature, the relative humidity increased 5 per cent. during the eclipse.

The main interest of the observations, however, centres in the influence of the eclipse on the diumal barometric curve. The diurnal march of the atmospheric pressure in these regions may well be classed among the most regularly recurring phenomena of terrestrial physics. From hourly observations made from April 25 to May 5 the mean at 10 a.m. was $29^{\circ} 957$ inches, and at 2 p.m. $29^{\circ} 84$ inches, the barometer thus falling in these four hours 0.113 inch. Between these hours, on May 6, the eclipse occurred, the total phase of the eclipse being from II. 32 to $11^{\prime} 37$ a.m. On that day the barometric curve presented a form wholly different from what is daily observed in these regions. From $10^{\circ} 30$ to $1 I^{2} 25$ a.m. the barometer fell with a greater rapidity than the normal rate of fall, being at II.20 a.m. 0.016 inch lower than the normal at that hour. Immediately thereafter a rapid and abnormal rise set in, the usual fall being arrested and replaced by an actual rise, so that while pressure at ir.20 a.m. was 29.927 inches, at I I.50 a.m. it was $29^{\circ} 940$ inches. At r2.10 p.m. it was o.o 9 inch above the normal for that hour. Since the barometer was 0.016 inch lower than the normal at II.20 a.m., and 0.019 inch higher at 12.10 p.m., it follows that the disturbance from the normal values during these fifty minutes occasioned by the eclipse amounted to 0.035 inch, being equal to nearly a third of the whole diurnal oscillation from the morning maximum to the afternoon minimum.

The time and manner of this abnormality is of special significance, inasmuch as it indicates a more rapid fall than the average during the first partial phase, when the sun's heat began to be cut off, and a rise above the average wholly exceptional after the close of the total phase, the maximum rise being delayed thirty-three

I Report of observations made on the expedition to Caroline Island to observe the total solar eclipse of May 6, r883, by Winslow Upton. (Washington, 1884 .)

minutes after the period of totality. An eclipse differs essentially from all other influences affecting the atmosphere, in that it cuts off the sun's heat from a restricted section of the earth's atmosphere extending from the surface to the extreme limits of the atmosphere, while from the air surrounding the shaded region the sun's heat is not cut off. Now, the observations showed that the first effect of the cutting off of the sun's rays and consequent reduction of the temperature, which no doubt extended through the whole height of the atmosphere, was to lower the pressure below the normal. This diminished tension was simply the direct result of the lowering of the temperature of the air over the region where the barometric observations were made.

Following this diminution of the pressure, an inflow of air towards the retreating path of the shadow set in, and pressure quickly rose above the normal of the hour, and as the sun's rays now heated the air with this excess thus temporarily accumulated over Caroline Island, pressure rose still further, till at thirty-three minutes after the close of the total phase it was o.org inch above the normal. Thereafter pressure fell with a corresponding rapidity during the next twenty minutes, at the close of which time it stood at the normal. The whole phases of the disturbance in the diurnal march of the pressure caused by the eclipse occupied two hours ending with $12.30 \mathrm{p} . \mathrm{m}$. It is from their bearings on the theory of the diurnal oscillations of the barometer that Mr. Upton's observations must be regarded as of the highest importance (see "Encyclopædia Britannica," Meteorology, pp. I 22 and 123).

Pointed attention is given in the report to the observations of the wind, which showed that, though the island is situated in the region usually included in the south-east trades, yet the direction of the wind was almost always noted as east or north-east, and was at no time observed to be from any other quarter than between north and east. Not a single observation during the time the expedition was on the island gave a direction south of east. The Challenger in this part of its cruise, during September, 1875 , noted the same directions of the wind, and during the cruise to southward the north-east trades were not left till lat $13^{\circ} \mathrm{S}$. was reached.

During the voyage from Callao, the Hartford sailed day after day in the region of the south-east trades, upon almost the same parallel of latitude, and with but few changes in the position of the sails, no steam being used. Since the conditions were so constant during the twentytwo days in which the vessel sailed in lat $11^{\circ} 5^{\prime} \mathrm{S}$. from long. $79^{\circ}$ to $137^{\circ} \mathrm{W}$, a tabulation of the hourly speed of the vessel day by day has been made from the ship's log. The mean values show a distinct increase in the evening, and a corresponding decrease in the morning, the maximum, 6.8 miles per hour, occurring at ro p.m., and the minimum, 5.9 miles, at Io a.m. With reference to the result, Mr. Upton remarks that, "It seems fair to attribute this to a diurnal variation in the wind's velocity. There is quite an unexpected regularity in the progression when we consider the approximate nature of the method. If not attributable to diurnal change in the wind itself, it yet indicates a diurnal change in the effect of the wind upon the sails, and is therefore of interest."

\section{SIR WILLIAM THOMSON ON MOLECULAR DYNAMICS ${ }^{2}$}

III.

BEFORE proceeding with new parts of this subject, I wish to say a few words about "fiddling while Rome is burning." Sir William Thomson writes to me that the expression was used while discussing some mathematical triviality, and he wishes to be relieved of the imputation

\footnotetext{
I Continued from p. 5ro.
} 